Canadian Studies in Population, Vol. 28(1), 2001, pp. 67-88

\title{
Lone-Father Families in Canada, 1971-1996
}

\author{
Kevin McQuillan \\ Marilyn Belle
}

Department of Sociology and Population Studies Centre

University of Western Ontario

London, Ontario, Canada

\begin{abstract}
Demographers and sociologists have paid considerable attention to the situation of lone-parent families. However, until recently, almost all of this work has focused on families headed by a lone mother. This paper seeks to fill an important gap in our knowledge of family change by examining the growth and characteristics of lone-father families in Canada. Using data from the public-use microfiles (PUMFs) of the census, the paper shows that the number of lonefather families has increased significantly in recent years, and that lone fathers are now younger and more likely to have become lone fathers through marital breakdown. The results also suggest that while lone-father families are not as economically disadvantaged as lone-mother families, income levels lag well behind those of two-parent families and have, in relative terms, declined in recent years.
\end{abstract}

Key Words: lone parents, lone-father families, fatherhood, poverty 


\begin{abstract}
Les démographes et sociologues se sont beaucoup attardés à la situation des familles monoparentales. Cependant, jusqu'à récemment, l'ensemble de ce travail ciblait surtout les mères seules. Cet article cherche à combler la brèche de notre connaissance des changements dans la famille en examinant l'augmentation du nombre de pères seuls au Canada et les caractéristiques de ces familles. Grâce aux données des microfilms à usage public du recensement, l'article illustre que le nombre de pères seuls a considérablement augmenté au cours des dernières années, que les pères seuls sont plus jeunes et que leur situation résulte vraisemblablement de la rupture de leur mariage. Les résultats indiquent aussi que bien que les familles dont le père est monoparental ne soient pas aussi défavorisées que les familles dont la mère est monoparentale, les niveaux de revenu accusent un certain retard par rapport aux familles biparentales et qu'ils ont relativement baissé au cours des dernières années.
\end{abstract}

Mots clés : Monoparental, pères seuls, paternel, pauvreté

\title{
Introduction
}

The study of lone-parent families has been high on the agenda of recent social science research (Biblarz and Gottainer, 2000; Eichler, 1997; Gairdner, 1992; McLanahan and Sandefur, 1994). The rapid growth in the number of families headed by a lone adult and the higher incidence of poverty and other social problems among such families have attracted the attention of demographers, sociologists, and others interested in social policy. Most of this attention has centred on the situation of lone-mother families. More than four-fifths of loneparent families in most industrialized countries are headed by a woman (Hudson and Galaway, 1993:336). And it is among mother-only families that the incidence of low income reaches strikingly high levels. The 1996 Canadian census indicates that $73 \%$ of families headed by a woman less than 35 years of age fell below the Statistics Canada Low Income Cut-Off.

The limited attention paid to male lone-parent families has usually been excused for two reasons. First, there have been relatively few such families. In 1976, there were fewer than 100,000 in Canada (McKie, 1993:54). This made it difficult for interested researchers to learn much about them since studies based on national samples would find very few cases for analysis. Beyond their small numbers, however, lone-father families were also seen as less problematic from a social policy perspective. Since the fathers were expected to be in the labour force, the incidence of poverty and associated social problems was assumed to be less. 
However, during the 1990s, researchers began to turn their attention to male lone-parent families (Des Rosiers and Le Bourdais, 1995; Eggebeen et al., 1996; Garasky and Meyer, 1996). One reason for this was a growing interest in the subject of fatherhood (Blankenhorn, 1995; Dulac, 1994; Harris et al., 1998; Marsiglio, 1995). There is renewed acknowledgment that fathers play an important role in the lives of their children, a role that extends beyond supplying a regular pay cheque (Marsiglio et al., 2000). At the same time, there is concern that problems that have long faced lone-mother families are affecting lone-father families as well. While lone-father families are, on average, better off financially than lone-mother families, poverty rates for father-only families are significantly higher than in two-parent families and appear to be on the rise (Brown, 2000:208; Farley, 1996:33; McKie, 1993:65).

The present paper has a modest goal. It seeks to describe the growth and change among lone-father families in Canada over the last generation. Drawing on the public-use microfiles of the Canadian censuses, the paper examines the changing demographic and economic characteristics of lone fathers and their families, and compares their situation to that of lone-mother and two-parent families. This analysis provides the essential background for more detailed studies of lone-parent living that can now be conducted using such data bases as the National Longitudinal Survey of Children and Youth (Marcil-Gratton and Le Bourdais, 1999).

\section{The State of Research on Lone-Father Families}

Significant growth in the number and proportion of lone-parent families in many industrialized countries in recent decades has spurred research into the sources of this demographic change and the implications of new family living arrangements for children and their parents (Golini and Silvestrini, 1997; Haskey, 1991) . A common theme in this literature is the reminder that loneparent families are not a new social phenomenon. Prior to World War II, the proportion of families headed by a lone parent equalled or exceeded recent figures in both Canada and the United States (e.g. Wargon, 1979). The proportion of families headed by a lone parent declined in the post-war period, largely due to improvements in rates of adult mortality. The 1960s marked another turning point as rising rates of divorce and increased numbers of births outside marriage led to substantial growth in the number and proportion of loneparent families, a trend that has continued to the present.

Throughout the 1960s and 1970s, families headed by lone mothers were growing at a more rapid pace than either husband-wife or lone-father families. Since 1980, however, research in Canada and the United States has pointed to significant growth in the number and proportion of lone-father families. Des Rosiers and Le Bourdais (1995:30) noted that the number of lone-father families 
increased by 35\% during the decade 1981-1991, while Garasky and Meyer (1996:391) reported a 42\% increase in the United States. The reasons for this shift are not entirely clear. Certainly, high rates of divorce, the fragility of many cohabiting unions, and the rising number of non-marital births have created the basis for more lone-parent families generally. Yet Garasky and Meyer (1996) suggest that growing acceptance of the idea that in some circumstances children are better off residing with their father has contributed to the increase in lonefather families. The growing popularity of joint or shared custody arrangements and an increasing say for older children in decisions about their living arrangements have replaced a situation in which children almost invariably remained with their mothers after the breakdown of a union.

A key issue that has heightened interest in the situation of lone-parent families is the economic disadvantage that many of these families confront. The seriousness of the problems that face lone-mother families is beyond dispute. It is widely recognized that the real income of mother-only families has consistently lagged well behind that of two-parent and even lone-father families (Ram, 2000; White and Rogers, 2000). However, there is less consensus on the severity of the problems faced by lone fathers. Earlier research indicated that lone fathers were about as likely to work full-time as were fathers in two-parent families, and, in an era where one-income earner was the norm for families, lone-father families were not seriously disadvantaged (Davids, 1985). Moreover, there may have been a selection factor operating with respect to the types of fathers who would gain custody of children. Hanson (1985), in a review of eleven American studies covering the period 1976-1984, found that lone fathers were better educated and held more prestigious jobs than did fathers from two-parent families. It may well have been the case that fathers needed greater "credentials" to gain custody at a time when the prevailing belief was that children were best confided to the care of their mothers.

More recent data from Canada and the United States are calling this finding into question. In the United States, White and Rogers (2000) found that while single-mother families experienced slight increases in real income during the 1980s, single-father families experienced an actual decline. Brown (2000) extended this analysis to cover the period 1984-1996 and concluded that lonefather families were at a significant and growing disadvantage in terms of income when compared to two-parent families. Bali Ram (2000) noted a similar trend in Canada, pointing to a larger decline in income in the period 1990-95 among lone-father families than occurred for lone-mother families.

The marked growth in the number of lone-father families in Canada and the suggestion that the characteristics of lone fathers may have changed significantly in recent years point to the need for a careful examination of their situation. In the remainder of the paper we will draw on data from the Canadian censuses to build a portrait of lone-father families in Canada in the period 19711996. 


\section{Census Data on Families}

The census is the only source of information that allows researchers to track changes in family structure over time. The census also contains rich data on the labour force involvement of family members, information that permits tracking the economic well-being of families. Since 1971, Statistics Canada has produced public-use microfiles (PUMFs) that allow researchers to do detailed analysis that previously required expensive special tabulations. As the publicuse files are based on sufficiently large samples, they support analysis of even relatively small categories of families, such as those headed by lone fathers, when the analysis is conducted at the national level.

The analysis in this paper focusses on what Statistics Canada defines as "census families." A census family consists of an opposite-sex couple living together with or without children, or a lone parent living with at least one never-married child. A potential problem for the analysis is that a change in the definition of family structure might affect the comparability of the data over time. Three issues are of particular concern. The first involves the change in the age cut-off for never-married children Prior to 1971, only never-married children under age 25 were considered to be part of the family (Harrison, 1979:38-40). Since then, never-married children of any age are counted as a part of the family so long as they reside with one or more of their parents. Thus, only when examining long-term trends in family structure does the change in the rule for including children have an effect.

A more serious concern centres on the possible effect of rising levels of cohabitation on census measures of family structure. Prior to 1976, the census carefully avoided the question of common-law unions and referred only to husband-wife and one-parent families. It is not clear how a father who was cohabiting with a partner who was not the mother of the children in the household would have classified himself. If the couple recorded themselves as married, the family would have been counted as a husband-wife unit. However, it is possible that some such families were actually recorded as lone-father families. Since 1976, the census instructions direct respondents to classify themselves as a married couple, and, in 1991, a specific question on commonlaw living was added to the census. Thus, the data for 1971 are a special source of concern. Wargon (1979:126) has observed that the number of young loneparent families may have been overestimated in the 1971 census. Although never fully resolved, Basavarajappa (1978) attributed the problem to difficulties in imputation procedures for individuals with missing data. It is not impossible, however, that some younger cohabiting couples were mistakenly classified as lone-parent families. This anomaly should be considered when examining the results for 1971 and when considering the magnitude of change between 1971 and 1976. 
Finally, the increasing rates of divorce and the break-up of cohabiting relationships that included children have meant that many Canadian children now spend time in different households. It is possible that the living arrangements for some of these children are mis-reported, and this could lead to an overestimate of the number of lone-father families. While we cannot dismiss this possibility, the census provides very clear instructions for recording persons who reside in the household. Children who normally reside with one parent and who were staying with the other parent on census day are to be recorded at their usual residence. If children spend equal amounts of time with each parent, they are to be recorded at the residence where they stayed on census day (Statistics Canada, 1999). Thus, it seems reasonable to conclude that the effect of visitation and custody arrangements on the measurement of family structure is small.

\section{Demographic Characteristics of Lone-Parent Families}

Table 1 provides an initial overview of the changes that have occurred in family structure since 1941. As mentioned above, the period from 1941-61 saw the ascendance of the two-parent family in Canada. By 1961, only 8.4\% of families were headed by a lone parent. Especially striking was the decline in the percentage of lone-father families, which fell from $3.2 \%$ in 1941 to just $1.8 \%$ in 1961. The increasing fragility of unions and the growing number of extramarital births contributed to a steady rise in the proportion of lone-parent families in the years since 1961. In the case of lone-father families, little change was evident until the 1980s. In the fifteen years from 1981-1996, however, the number of lone-father families grew from 124, 200 to 192, 275, while the percentage of all families headed by a lone father rose to the highest level since 1941.

These figures, often quoted in both social science articles and in the popular media, do not really speak to the issue that concerns most people when the problems of lone-parent families are discussed. The image that comes to mind is of a lone adult struggling to care and provide for young children. Yet, since 1971, the census data include all families with a never-married child living with a parent. To better focus the analysis on the changing family environment of children, the data used in the remainder of this paper include only those families with at least one child less than eighteen years of age.

Table 2 shows the distribution of such families for the period from 1971-1996. The proportion of families headed by a lone parent continues to rise, moving up from approximately one in ten families in 1971 to almost one in five in 1996. 


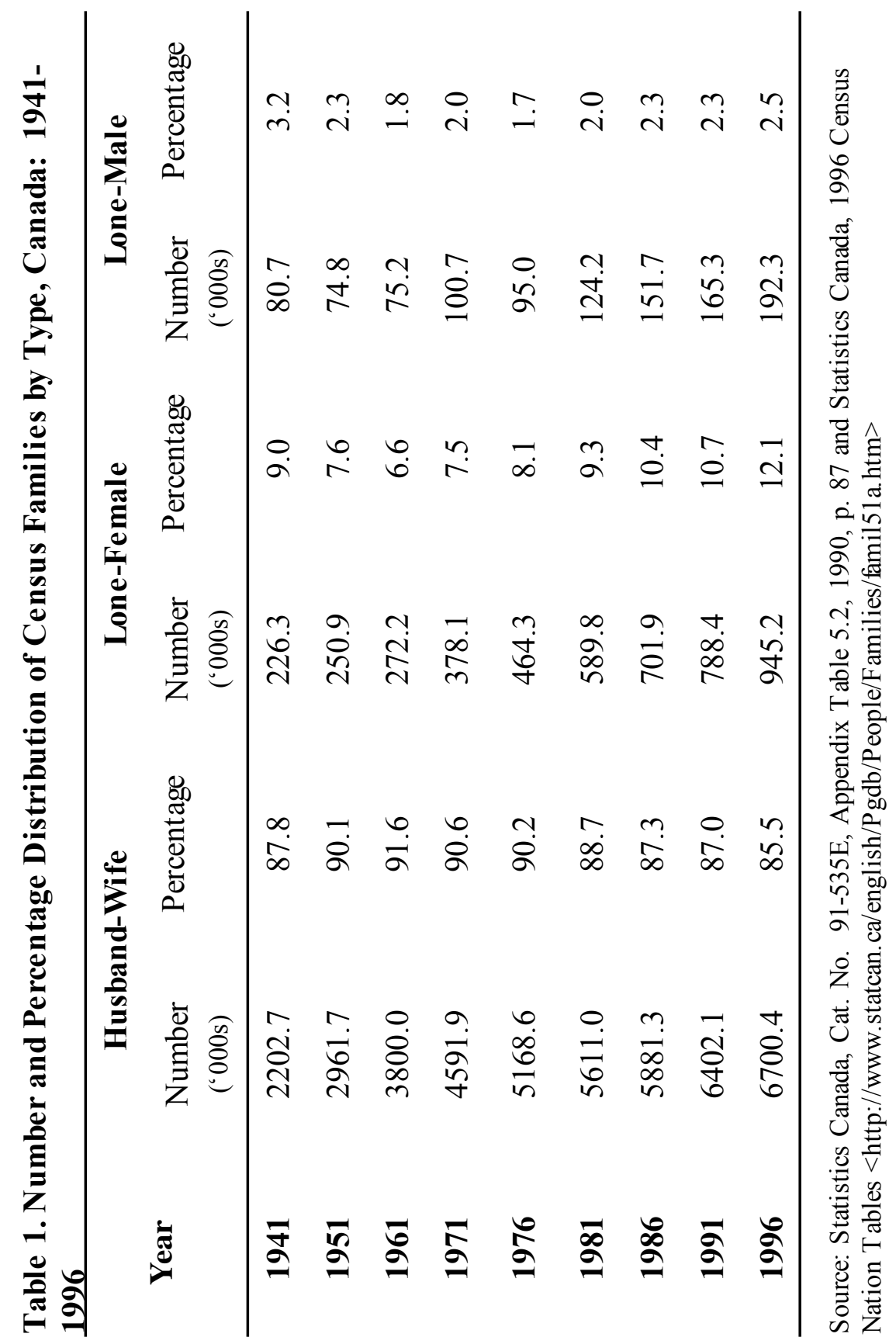


Table 2

Percentage Distribution of Families with at Least

One Child Under 18 by Family Structure, Canada: 1971-1996

\begin{tabular}{cccc}
\hline Year & $\begin{array}{c}\text { Two- } \\
\text { Parent }\end{array}$ & $\begin{array}{c}\text { Lone- } \\
\text { Female }\end{array}$ & $\begin{array}{c}\text { Lone } \\
\text { Male }\end{array}$ \\
\hline $\mathbf{1 9 7 1}$ & 90.1 & 7.7 & 2.2 \\
$\mathbf{1 9 7 6}$ & 89.1 & 9.1 & 1.8 \\
$\mathbf{1 9 8 1}$ & 86.8 & 11.1 & 2.1 \\
$\mathbf{1 9 8 6}$ & 84.4 & 13.1 & 2.5 \\
$\mathbf{1 9 9 1}$ & 83.5 & 13.9 & 2.7 \\
$\mathbf{1 9 9 6}$ & 80.7 & 16.4 & 2.9 \\
\hline
\end{tabular}

Source: Census of Canada, Public-use micro files

As expected, most of these families were headed by women. But the number and proportion of lone-father families have grown as well, and by 1996, 111,000 families or almost $3 \%$ of families with a child under eighteen were headed by a lone male.

Figures 1 and 2 provide more information about the characteristics of these families. Much of the concern about the growth of lone parenthood has centred on the ability of lone parents to support themselves and their children. This, in turn, is linked to the changing demographics of these families. When the parents and children in the family are older, it is easier for the lone parent to work outside the home and more likely that some of the children will contribute to the family income. In the earlier part of this century, this was very often the case. Indeed, as late as 1971, more than one-third of lone mothers were fortyfive years of age or older. In the last twenty-five years, however, this distribution has shifted, and more lone mothers are now young women struggling to support dependent children. In 1996, almost half were under thirty-five, and less than one in six was past age forty-five. This shift in the age distribution has come more slowly to lone fathers. In 1981, more than $40 \%$ were over forty-five years of age, but, by 1996, the proportion over forty-five had declined to less than $30 \%$. 


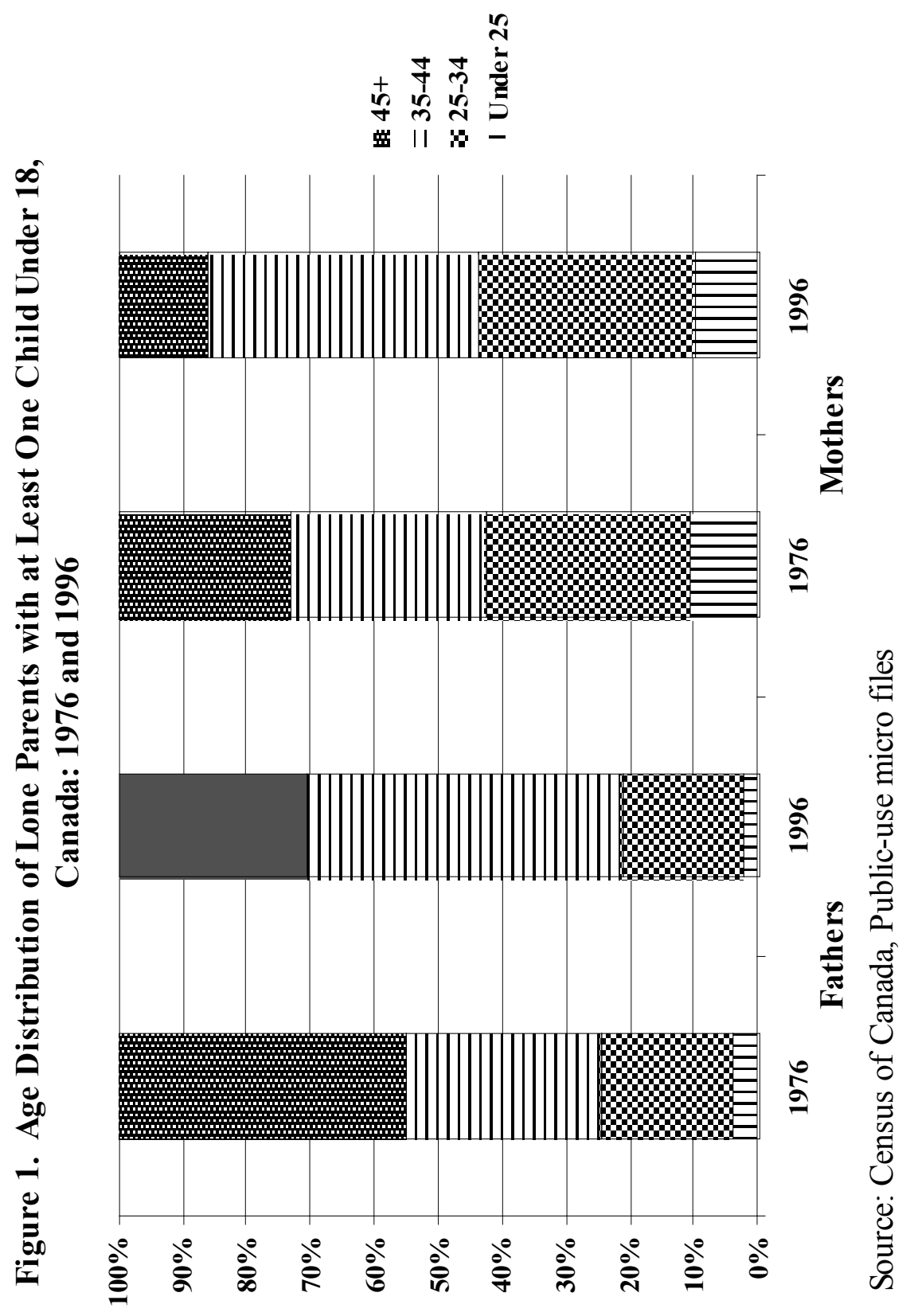




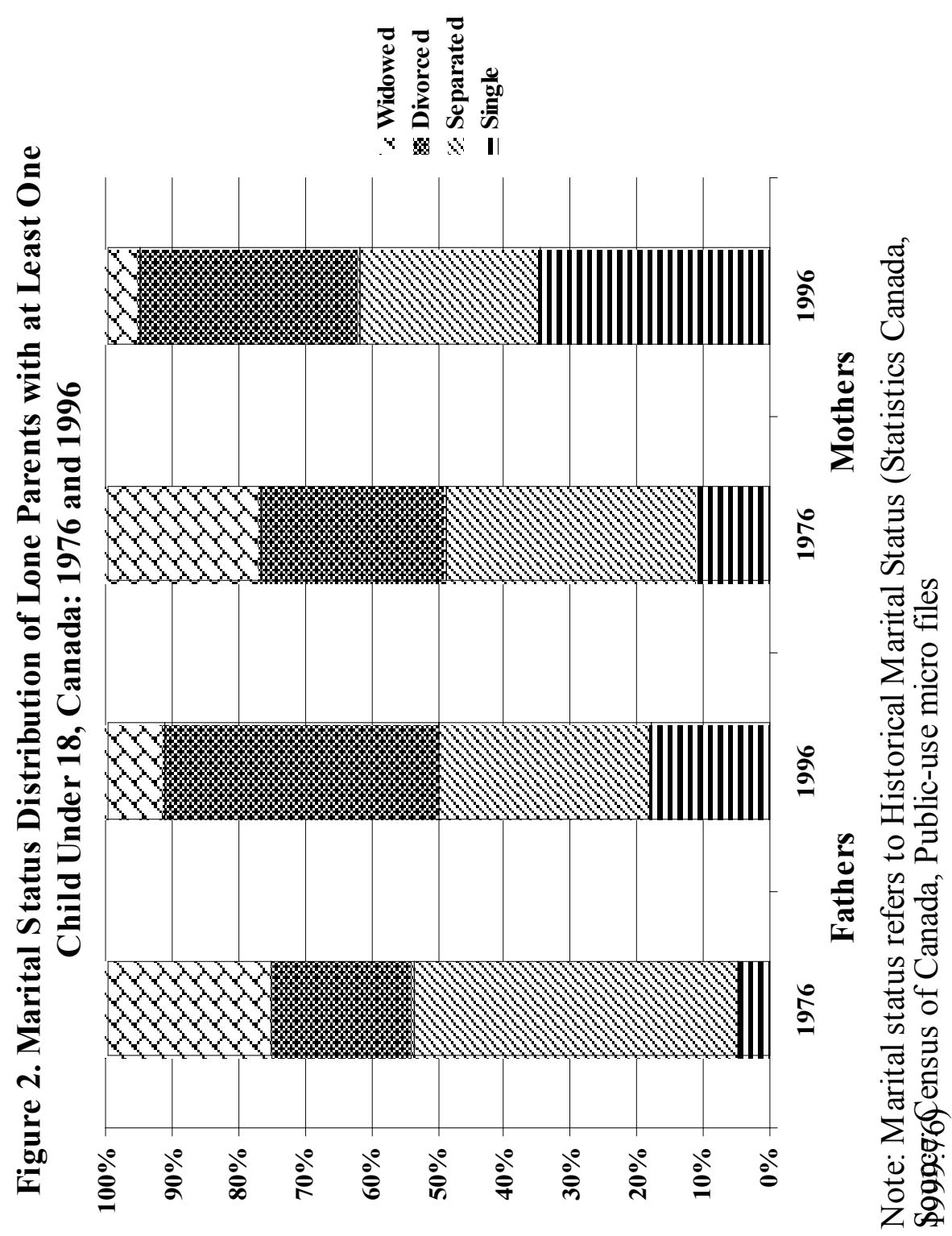


A major reason for the shift in the age distribution of lone parents has been the change in the demographic antecedents of lone parenthood. Prior to 1971, the majority of lone parents were widowed. However, by 1996, only about 5\% of lone mothers were widows, while just $8.6 \%$ of lone fathers were widowers. Separation and divorce are now the most common route to lone parenthood, although an increasing number of lone parents have never been a party to a legal marriage. In 1996, just over one-third of lone mothers and almost one in five lone fathers had never married. The increasing popularity of common-law unions and their greater instability (Marcil-Gratton and Le Bourdais, 1999; Seltzer, 2000; Wu, 2000) suggest that this route will grow in importance in the future.

While lone fathers and lone mothers tend to be similar in terms of the number of children for whom they are responsible (Péron et al., 1999:92-93), they do differ with respect to the ages of the children in their care. The younger the children in the family, the less likely it is that a lone father will head the family. In 1996, only $1.6 \%$ of families with a child less than six were headed by a lone father. This figure rose to $3.7 \%$ for families where the youngest child was between 7 and 14 , and to $5.7 \%$ where the youngest child was $15-17$ years old.

\section{Economic Status of Families}

Lone-parent families have been a focus of public policy concern for some time because a growing amount of social science research suggests that the parents and children in these families are at higher risk of experiencing a number of negative outcomes. Children in lone-parent families have been shown to be more likely to encounter problems in the educational system, to be at higher risk of developing behavioural problems that may lead to troubles with the law, and to be more likely to experience early entry into marriage or cohabiting relationships or to experience a non-marital birth (Kiernan, 1992; Le Bourdais and Marcil-Gratton, 1998; Lipman et al., 1998; McLanahan and Sandefur, 1994; Ross et al., 1998). An intense debate has ensued over the sources of their disadvantage, with some arguing that the family structure effect is negligible when the economic deprivation of these families is taken into account, while others claim that the absence of a parent and the differing social experiences of lone-parent families place additional strains on the parents and children beyond those imposed by economic disadvantage. In one comprehensive review of the American situation, McLanahan (1997) concluded that about half of the disadvantage encountered by children of lone-parents was a result of poverty, while the other half was attributable to other dimensions of the life of loneparent families.

Again, most of the attention in this literature has focused on lone-mother families. It is well known that such families face enormous economic difficulties and poverty rates among these families can reach very high levels. 
Moreover, as the proportion of lone-mother families has grown, these families have come to make up a very high percentage of the families living below the poverty line. Part of the economic disadvantage mother-only families face results from the low level of earnings of the mother. The presence of young children makes participation in the labour force difficult, and when the mother does work, limited human capital and low wages in the labour market often mean that family income is very low. Rather less attention has been paid to the economic situation of lone-father families, in part because it was assumed that the fathers are more likely to be working and earning sufficient income to keep the family out of poverty. The changing demographics of lone-father families described above make it important to examine whether or not father-only families continue to escape the financial problems that plague female loneparent families.

Figure 3 shows the total family income (before tax) of male and female loneparent families as a percentage of the average income received by two-parent families for the period from 1971-1996. Two facts stand out. The first is that the economic problems of lone-father families have not been as severe as those faced by mother-only families. At each point in time, the income of lone-father families significantly exceeded that received by lone-mother families. At the same time, it is evident that the advantage enjoyed by lone-father families relative to lone-mother families has been eroding over time. In 1981, the total income of father-only families was $76 \%$ of that received by two-parent families, while the income of lone-mother families fell below $40 \%$ of the two-parent figure. In the last fifteen years, however, while the figure for mother-only families has remained nearly constant, the relative position of male lone-parent families has deteriorated significantly. In 1996, the total income of these families amounted to only $58 \%$ of the income enjoyed by two-parent families. As a result, $28.8 \%$ of lone-father families fell below the Statistics Canada LowIncome Cut-Off in 1996 (see Figure 4). This figure is still far below the 58.6\% level for mother-only families, but is more than double the rate $(13.3 \%)$ for married-couple families.

To understand the declining economic status of lone-father families requires looking more closely at the components of family income. Earnings through wages and salary or self-employment continue to be the largest element of family income for all family types. As Figure 5 shows, in 1996, earnings accounted for almost $90 \%$ of the income received by two-parent families, and even among female lone-parent families, earnings made up almost $60 \%$ of income. For lone-father families as well, earnings were the largest source of income. But their earnings as a percentage of the earnings of two-parent families have fallen sharply in recent years. The earnings of father-only families slipped from $73 \%$ of the two-parent figure in 1981 to just $54 \%$ in 1996, parallelling the relative decline in total income. 


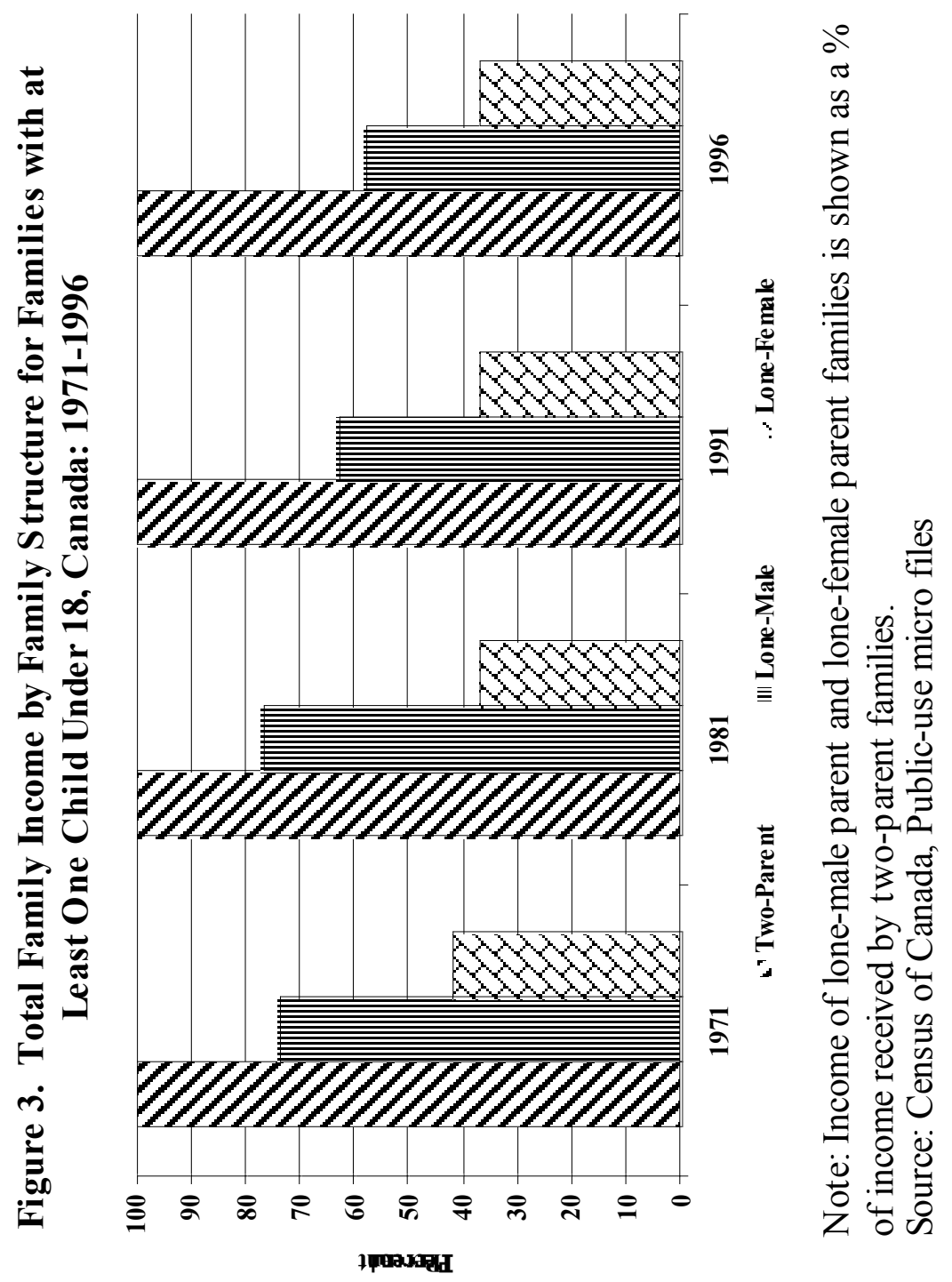


K. McQuillan and M. Belle

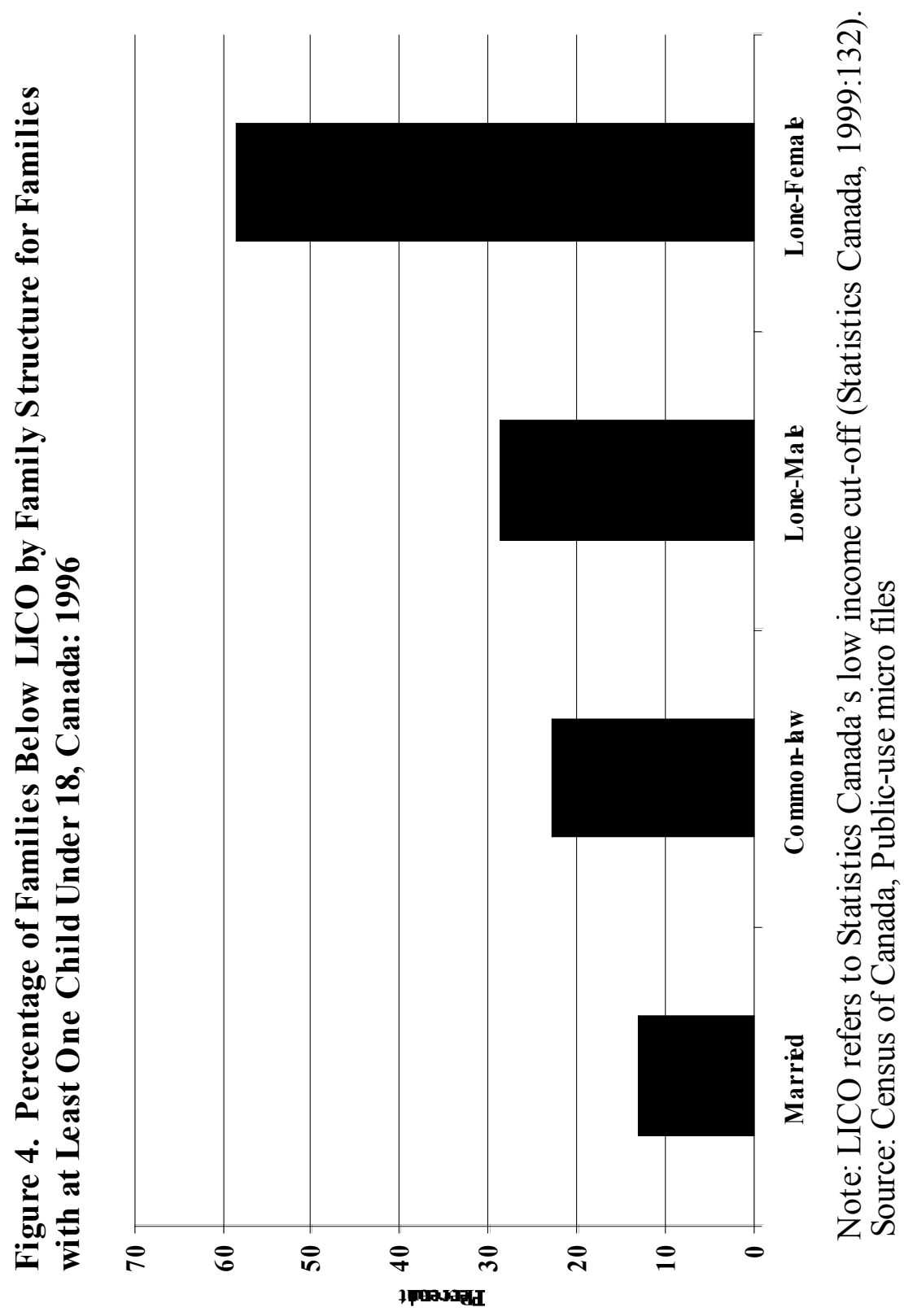




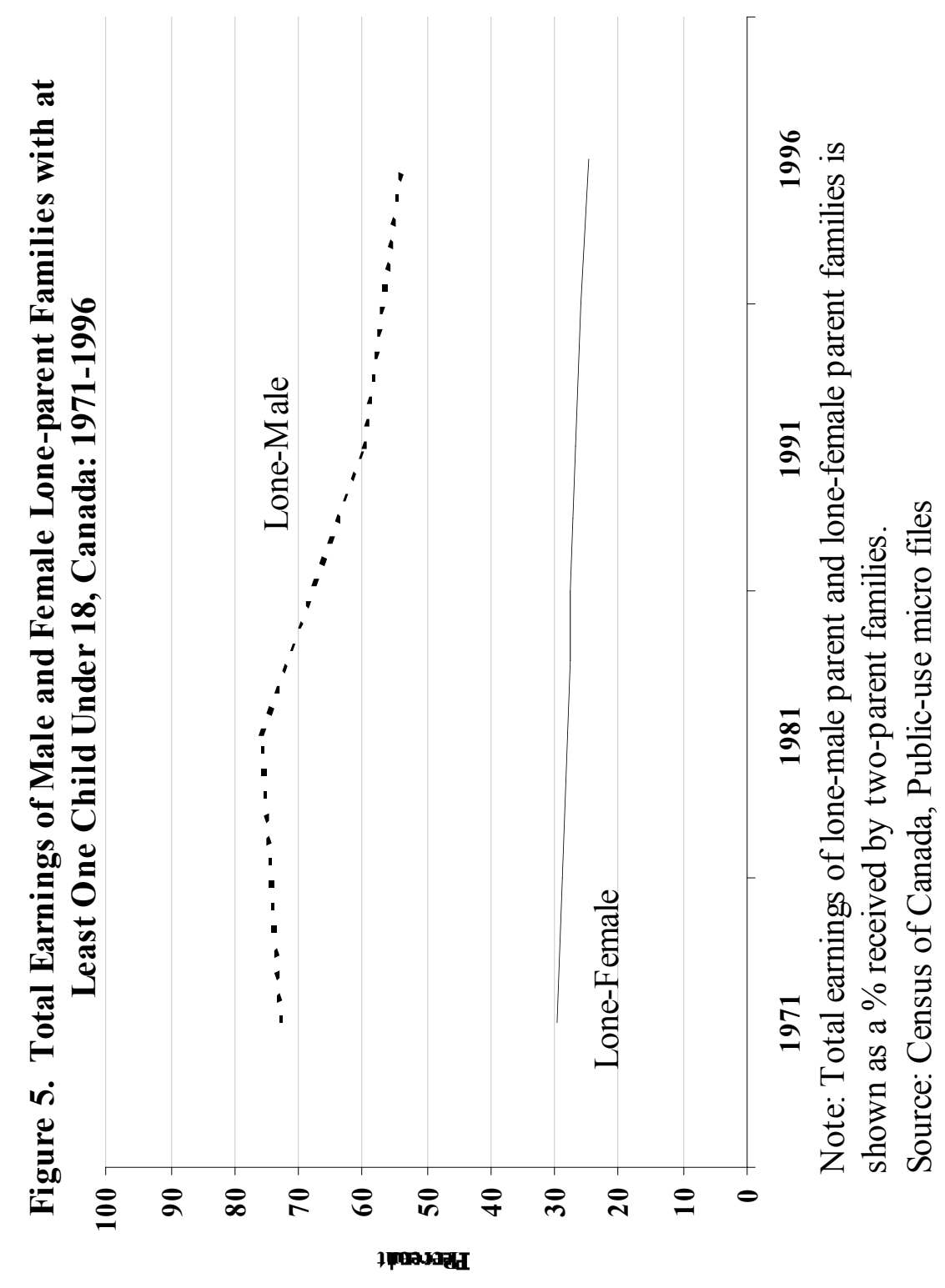


The relative decline in the earnings of father-only families appears to result from two factors. First, as Table 3 indicates, the average number of earners has declined in both lone-father and lone-mother families, but has increased in husband-wife families. While lone parents bring home almost all the earnings in their families, the dramatic rise in labour force participation among mothers in two-parent families has allowed them to increase their real income at a time when male wages have been largely stagnant. The growing disparity in the number of earners is perhaps the most important factor underlying the widening income gap between two-parent and lone-parent families.

A second factor that has also contributed to the growing disadvantage of lonefather families relates to the earnings of fathers in two-parent and lone-father families. The earnings of lone fathers as a percentage of the income earned by fathers in two-parent families has declined significantly. From $88 \%$ in 1981, a lone father's relative earnings dropped to $77 \%$ in 1996 . This contrasts with the situation of lone mothers, whose earnings as a percentage of those of fathers in two-parent families actually increased slightly since 1981, albeit from a very low starting point.

Table 3

Average Number of Earners by Family Structure, Canada: 1971-1996

\begin{tabular}{cccc}
\hline Year & $\begin{array}{c}\text { Two- } \\
\text { Parent }\end{array}$ & $\begin{array}{c}\text { Lone- } \\
\text { Female }\end{array}$ & $\begin{array}{c}\text { Lone- } \\
\text { Male }\end{array}$ \\
\hline $\mathbf{1 9 7 1}$ & 1.67 & .96 & 1.27 \\
$\mathbf{1 9 8 1}$ & 1.86 & .95 & 1.37 \\
$\mathbf{1 9 9 1}$ & 1.96 & .88 & 1.17 \\
$\mathbf{1 9 9 6}$ & 1.92 & .79 & 1.01 \\
\hline
\end{tabular}

Source: Census of Canada, Public-use micro files 


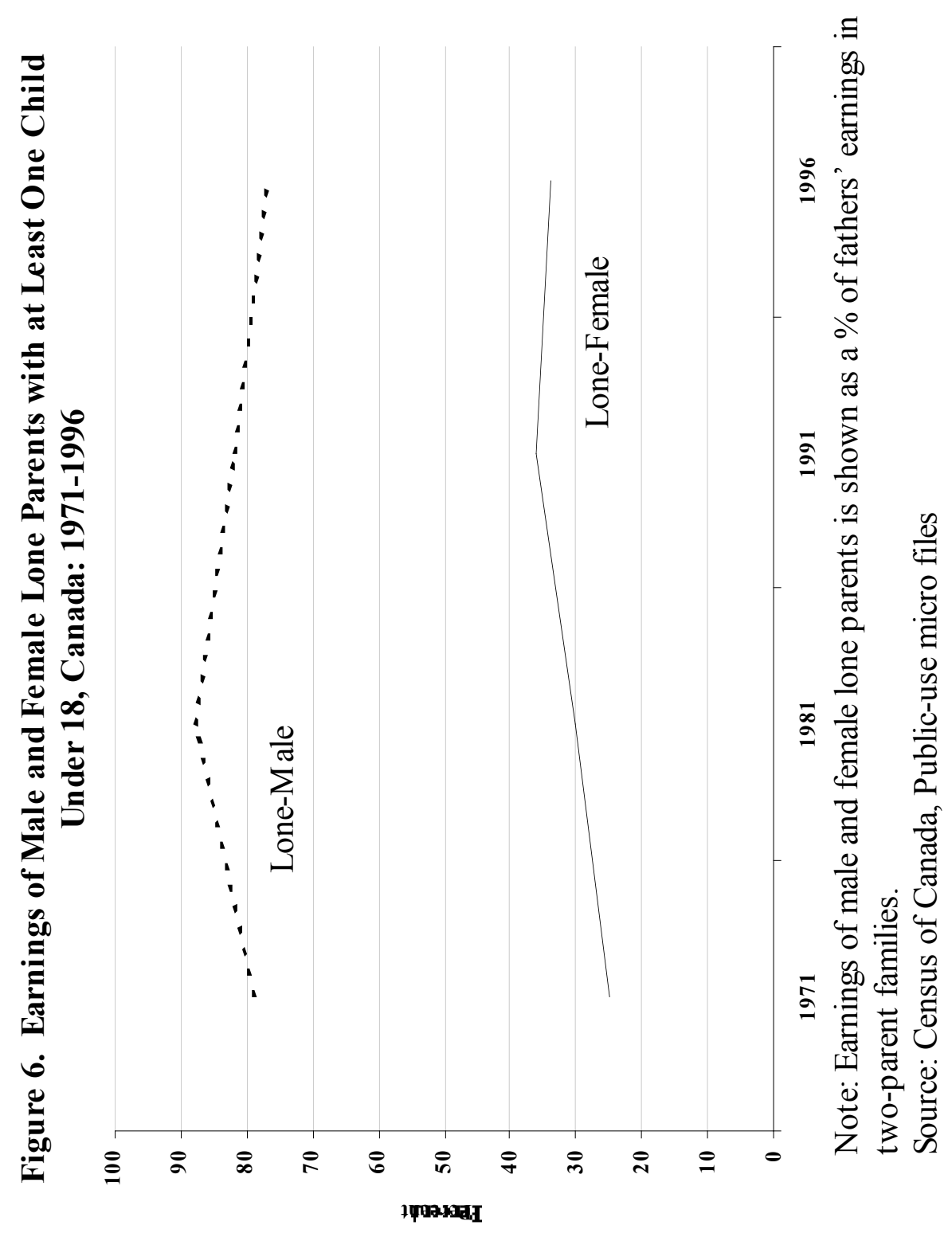


This difference in earnings is itself a reflection of changes in the labour force activity of lone parents. The data in Table 4 show the labour force activity of parents in the week prior to the census. Both male and female lone parents were less likely to be working (either full-time or part-time) than their counterparts in two-parent families.

Table 4

Percentage of Parents Employed (Full-time or Part-time)

by Family Structure, Canada: 1996

\begin{tabular}{ccc}
\hline $\begin{array}{c}\text { Family } \\
\text { Structure }\end{array}$ & Mothers & Fathers \\
\hline Lone Parent & 55.2 & 75.9 \\
Common-law & 57.1 & 78.3 \\
Married Couples & 65.2 & 88.4 \\
\hline
\end{tabular}

Source: Census of Canada, Public-use micro files

\section{Conclusion}

Lone-father families constitute a small but growing part of the family landscape in Canada. They are a distinctive group in that their experiences contrast with those of both two-parent and lone-mother families. Several American studies have pointed to the "in-between" status of lone-father families (Bianchi, 1995; Meyer and Garasky, 1993). In other words, on many dimensions, they stand somewhere in-between the very disadvantaged status of female lone-parent families and the more secure situation of most two-parent families. In the Canadian case, this seems true as well. Lone fathers are significantly more likely to be in the labour force than lone mothers but less likely than fathers in two-parent families. Their incomes are lower and poverty rates higher than twoparent families, yet they do not experience the extreme disadvantage of lonemother families.

What is worrisome from a social policy perspective is that the situation of these families, at least in relative terms, is deteriorating. When one-earner families were the norm, lone-father families experienced an economic situation similar to 
two-parent families. The dramatic rise in the labour force participation rates for mothers in two-parent families and the changing demographics of lone-father families have widened the gap between these two types of families. Lone-father families have fallen significantly behind two-parent families and are now at a substantially higher risk of living in poverty.

Extending our knowledge of lone-father families should be high on the agenda of social policy research. We need to know more about the consequences of life in these families for both fathers and children. Does the "in-between" status of these families extend to the outcomes for children? If the children of lone-father families fare better than those who have lived in female lone-parent families is this because of the greater economic health of the family or for other reasons not immediately apparent. As we have seen, lone fathers are significantly more likely to be in the labour force than lone mothers. Is this because lone fathers receive more help from others that makes employment more manageable? Past research has shown that lone-father families are more likely to reside with others (Péron et al., 1999:35). Who are these co-residents and what help do they provide? With the new sources of data on family life that are now available to Canadian researchers, we can look forward to finding answers to these questions in the years ahead.

\section{References:}

Basavarajappa, K.G. 1978. Marital Status and Nuptiality in Canada. Profile Studies, 1971 Census of Canada. Cat. No. 99-704, Ottawa: Statistics Canada.

Bianchi, Suzanne M. 1995. "The changing demographic and socioeconomic characteristics of single parent families," Marriage and Family Review 20:71-97.

Biblarz, Timothy J. and Greg Gottainer. 2000. "Family structure and children's success: A comparison of widowed and divorced single-mother families," Journal of Marriage and the Family 62: 533-548.

Blankenhorn, David. 1995. Fatherless America. New York: Harper Perennial Publishers.

Brown, Brett V. 2000. "The single-father family: Demographic, economic, and public transfer use characteristics," Marriage and Family Review 29: 203-220.

Davids, Leo. 1985. "The lone parent family in Canada: the quantitative background," in Benjamin Schlesinger (ed.), The One-Parent Family in the 1980s. Toronto: University of Toronto Press, pp. 1-12. 
Des Rosiers, Hélène and Céline Le Bourdais. 1995. "New forms of male family life in Canada," in Mirjam C. P. van Dongen, Gerard A. B. Frinking and Menno J. G. Jacobs (eds.), Changing Fatherhood: An Interdisciplinary Perspective. Amsterdam: Thesis Publishers, pp. 2959.

Dulac, Germain. 1994. "The changing faces of fatherhood," Transition 12-15.

Eggebeen, David J., Anastasia R. Snyder and Wendy D. Manning. 1996. "Children in single-father families in demographic perspective," Journal of Family Issues 17(4):441-465.

Eichler, Margrit. 1997. Family Shifts Families, Policies, and Gender Equality. Toronto: Oxford University Press.

Farley, Reynolds. 1996. The New American Family. New York: Russell Sage Foundation.

Gairdner, William D. 1992. The War Against the Family. Toronto: Stoddart.

Garasky, Steven and Daniel R. Meyer. 1996. "Reconsidering the increase in father-only families," Demography 33(3): 385-393.

Golini, Antonio and Angela Silvestrini. 1997. "Family change, fathers and children in Western Europe: a demographic and psychosocial perspective," in Solly Dreman (ed.), The Family on the Threshold of the $21^{\text {st }}$ Century: Trends and Implications. New Jersey: Lawrence Erlbaum Associates, pp. 201-228.

Hanson, Shirley M. H. 1985. "Single fathers with custody: a synthesis of the literature," in Benjamin Schlesinger (ed.), The One-Parent Family in the 1980s. Toronto: University of Toronto Press, pp. 57-96.

Harrison, Brian R. 1979. A user's guide to 1976 census data on households and families. Working paper No. 1-HF 79, Housing and Families Group, Ottawa: Statistics Canada.

Harris, Kathleen Mullan, Frank F. Furstenberg, Jr. and Jeremy K. Marmer. 1998. "Paternal involvement with adolescents in intact families: the influence of fathers over the life course," Demography 35(2): 201-216.

Haskey, John. 1991. "Lone parenthood and demographic change," in Michael Hardey and Graham Crow (eds.), Lone Parenthood Coping with Constraints and Making Opportunities in Single-parent Families. Toronto: University of Toronto Press, pp. 19- 46. 
Hudson, Joe and Burt Galaway. 1993. "Directions for future research," in Joe Hudson and Burt Galaway (eds.), Single Parent Families. Toronto: Thompson, pp. 335-349.

Kiernan, Kathleen E. 1992. "The impact of family disruption in childhood on transitions made in young adult life," Population Studies 46: 213-234.

Le Bourdais, Céline and Nicole Marcil-Gratton. 1998. "The impact of family disruption in childhood on demographic outcomes in young adulthood," in Miles Corak (ed.), Labour Markets, Social Institutions, and the Future of Canada's Children. Catalogue no. 89-553- XPB, Ottawa: Statistics Canada, pp. 91-105.

Lipman, Ellen L., Michael H. Boyle, Martin D. Dooley, and David R. Offord. 1998. Children and Lone-Mother Families: An Investigation of Factors Influencing Child Well-Being. Ottawa: HRDC, Applied Research Branch, Research Report W-98-11E.

Marcil-Gratton, Nicole and Céline Le Bourdais. 1999. Custody, Access and Child Support: Findings from The National Longitudinal Survey of Children and Youth. Ottawa: Department of Justice, Child Support Team, Research Report CSR-1999-3E.

Marsiglio, William. 1995. "Fatherhood scholarship: An overview and agenda for the future," in William Marsiglio (ed.), Fatherhood: Contemporary Theory, Research, and Social Policy. Thousand Oaks: Sage Publications, pp. 1-20.

Marsiglio, William, Paul Amato, Randal D. Day, and Michael E. Lamb. 2000. "Scholarship on fatherhood in the 1990s and beyond," Journal of Marriage and Family 62: 1173-1191.

McKie, Craig. 1993. "An overview of lone parenthood in Canada," in Joe Hudson and Burt Galaway (eds.), Single Parent Families. Toronto: Thompson, pp. 53-72.

McLanahan, Sara S. 1997. "Parent absence or poverty: Which matters more?" in Greg J. Duncan and Jeanne Brooks-Gunn (eds.), Consequences of Growing Up Poor. New York: Russell Sage Foundation, pp. 35-48.

McLanahan, Sara S. and Gary D. Sandefur. 1994. Growing Up with a Single Parent: What Hurts and What Helps. Cambridge, Massachusetts: Harvard University Press. 
Meyer, Daniel R. and Steven Garasky. 1993. "Custodial fathers: Myths, realities, and child support policy," Journal of Marriage and the Family 55:73-89.

Pèron, Yves, Hélène Des Rosiers, Heather Juby, Evelyne Lapierre-Adamcyk, Céline Le Bourdais, Nicole Marcil-Gratton, and Jael Mongeau. 1999. Canadian Families at the Approach of the Year 2000. Cat. No. 96-321, no. 4, Ottawa: Statistics Canada.

Ram, Bali. 2000. "Current issues in family demography: Canadian examples," Canadian Studies in Population 27: 1-41.

Ross, David P., Paul A. Roberts, and Katherine Scott. 1998. Variations in Child Development Outcomes among Children Living in Lone-Parent Families. Research Report W-98-7E, Ottawa: HRDC, Applied Research Branch.

Seltzer, Judith A. 2000. "Families formed outside of marriage," Journal of Marriage and the Family 62: 1247-1268.

Statistics Canada. 1999. 1996 Census Dictionary. Final Edition Reference. Cat. No. 92-351- UPE. Ottawa: Minister of Industry.

Wargon, Sylvia T. 1979. Canadian Households and Families: Census Analytical Study. Ottawa: Statistics Canada.

White, Lynn and Stacy J. Rogers. 2000. "Economic circumstances and family outcomes: A review of the 1990s," Journal of Marriage and the Family 62: 1035-1051.

Wu, Zheng. 2000. Cohabitation: An Alternative Form of Family Living. Toronto: Oxford University Press.

Manuscript Received July 2000; Manuscript Revised February 2001 